\title{
PENGARUH VITAMIN C DALAM PAKAN TERHADAP SINTASAN, PERTUMBUHAN DAN STRES LARVA BANDENG (Chanos chanos)
}

\author{
Ketut Suwirya* , Agus Prijono*) dan Tony Setiadharma*)
}

\begin{abstract}
ABSTRAK
Vitamin C adalah salah satu nutrien yang penting pada pakan ikan. Banyak jenis ikan sangat sensitif terhadap kekurangan vitamin C. Kebutuhan kuantitatif akan vitamin $\mathrm{C}$ untuk mendapatkan pertumbuhan ikan yang optimum sangat bervariasi tergantung jenis dan ukuran ikan. Percobaan ini dilaksanakan untuk menentukan kebutuhan vitamin $\mathrm{C}$ larva ikan bandeng. Pakan dibuat dengan kandungan vitamin $\mathrm{C}$ yang berbeda yaitu $0,500,1.000$, dan $1.500 \mathrm{mg} / \mathrm{kg}$ pakan, diberikan pada larva yang berumur 10 hari selama 15 hari dalam lingkungan air laut. Larva yang diberi pakan dengan kandungan vitamin $\mathrm{C} 0 \mathrm{mg} / \mathrm{kg}$ menunjukkan sintasan paling rendah dibandingkan dengan perlakuan lainnya, tetapi pertumbuhan yang lebih baik dicapai dengan kandungan vitamin C $1.000 \mathrm{mg} / \mathrm{kg}$ pakan atau lebih. Kandungan vitamin $\mathrm{C}$ di dalam tubuh meningkat dengan peningkatan kandungan vitamin $\mathrm{C}$ dalam pakan. Di samping itu larva yang diberi pakan dengan kandungan vitamin C 1.000 dan $1.500 \mathrm{mg} / \mathrm{kg}$ pakan lebih tahan terhadap stres dibandingkan dengan yang diberi pakan dengan kandungan vitamin $\mathrm{C}$ sebesar 0 dan $500 \mathrm{mg} / \mathrm{kg}$ pakan.
\end{abstract}

ABSTRACT: Effect of vitamin C in the diets on survival, growth rate and stress of milkfish (Chanos chanos) larvae. By: Ketut Suwirya, Agus Prijono, and Tony Setiadharma.

Vitamin $C$ is an important nutrient in fish feed. Most fishes cire extremely sensitive to vitamin $C$ deficiency. Quantitative requirement of vitamin C for optimum fish growth varies among species and size of fish. This experiment is conducted to determine vitamin $C$ requirement of milkfish larvae. Diets suplemented with different levels of vitamin Cat 0;500;1,000; and 1,500 $\mathrm{mg} / \mathrm{kg}$ diets were fed to the ten-day old milkfish larvae for 15 days in sea waters. Larvae given feed without vitamin $C$ showed the lowest survival rate compare to vitamin $C$ added feed. Better growth result was obtained with vitamin C level of $1000 \mathrm{mg} / \mathrm{hg}$ or greater. The vitamin $C$ content in the body increased with the increasing of dietary level of vitamin $C$. Larvae fed with level of vitamin $C$ at 1,000 and $1,500 \mathrm{mg} / \mathrm{kg}$ diets were also more resistant to stress than those fed with 0 and $500 \mathrm{mg} /$ $\mathrm{kg}$ vitamin $\mathrm{C}$ containing diets.

KEYWORDS: vitamin C, milkfish larvae, survival rate, stress.

\section{PENDAHULUAN}

Sampai saat ini produksi benih ikan bandeng masih sangat tergantung pada pakan alami seperti rotifer. Nilai nutrisi pakan alami ini bervariasi dan sangat bergantung pada musim. Pada musim hujan pertumbuhan Chlorella sebagai pakan rotifer sangat sulit, sehingga kualitas rotifer juga menurun. Hal ini menyebabkan produksi dan kualitas benih ikan bandeng menjadi tidak stabil. Oleh karena itu perlu dikembangkan pakan buatan larva bandeng sebagai substitusi pakan alami.

Telah banyak diketahui bahwa vitamin $\mathrm{C}$ merupakan salah satu nutrien yang esensial pada ikan (Lovell, 1973). Kitamura et al. (1965) menunjukkan bahwa ikan membutuhkan vitamin C. Untuk memenuhi kebutuhan ini, maka vitamin $\mathrm{C}$ harus tersedia dalam pakan. Ikeda \& Sato (1965) menyatakan bahwa ikan tidak mempunyai kemampuan untuk mensintesis vitamin C.

Tanda-tanda kekurangan vitamin C pada ikan telah banyak dilaporkan. Tanda-tanda tersebut. antara lain lordosis atau sokoliosis dengan tingkat sintasan yang rendah pada ikan brook trout (Poston, 1967), coho salmon dan rainbow trout (Halver et al., 1969) dan lele (Lovel, 1973); kerusakan filamen insang pada coho salmon dan rainbow trout (Halver et al., 1969), serta pertumbuhan yang rendah pada ikan red sea bream (Yano, 1975).

Kebutuhan vitamin C pada ikan untuk mendapatkan pertumbuhan yang optimum sangat bervariasi tergantung pada spesies dan umur atau ukuran ikan. Halver et al. (1969) menunjukkan bahwa yuwana ikan trout membutuhkan $100 \mathrm{mg} /$

Peneliti pada Loka Penelitian Perikanan Pantai Gondol 
kg pakan, sedangkan yuwana ikan salmon hanya membutuhkan $50 \mathrm{mg} / \mathrm{kg}$ pakan. Kebutuhan vitamin C sejenis ikan lele $(2.3 \mathrm{~g})$ untuk pertumbuhan yang optimum adalah $50 \mathrm{mg} / \mathrm{kg}$ pakan (Andrews \& Murai. 1975), akan tetapi Robinson (1984) menyarankan penambahan vitamin $\mathrm{C}$ sebanyak $375 \mathrm{mg} / \mathrm{kg}$ pakan untuk mengantisipasi hilangnya vitamin tersebut selama proses pembuatan dan penyimpanan.

Informasi kebutuhan vitamin $\mathrm{C}$ dalam pakan larva bandeng masih sangat terbatas. Oleh karena itu percobaan ini dilaksanakan untuk mengetahui pengaruh vitamin $\mathrm{C}$ terhadap sintasan, pertumbuhan, dan daya tahan benih bandeng, sekaligus untuk mendapatkan dosis optimum vitamin $\mathrm{C}$ clalam pakan.

\section{BAHAN DAN METODE}

Percobaan ini mengunakan bak silinder ukuran $1 \mathrm{~m}^{3}$ sebanyak 12 buah dan diisi air laut sebanyak $70 \%$. Setiap bak diisi larva yang baru menetas (D. 0) sebanyak 10.000 ekor. Larva dipelihara sampai berumur 10 hari (D-10) dan diberi pakan rotifer dan Chlorella dengan kepadatan yang disesuaikan dengan umur larva yaitu masing-masing 10-40 individu dan 1 juta sel per $\mathrm{mL}$.
Pada umur 11 hari (D-11) larva mulai diberi pakan buatan dengan kandungan vitamin (Yang berbeda sehagai perlakuan yaitu $0,500.1 .000$. (liın $1.500 \mathrm{mg}$ per kg pakan. Adapun komposisi pakan percobaan seperti pada Tabel 1. Jenis vitamin ( yang digunakan adalah jenis L-ascorbyl-2. phosphate $\mathrm{Mg}$ (AAP). Jenis vitamin ini mempunyai stabilitas dan aktivitas yang tinggi (Lovell \& Neggar, 1990; Gadient \& Fenster, 1994: Miyasalis. 1995 ).

Kadar vitamin C (L-asam askorbik) dalam pakan dan tubuh larva dianalisis dengan menggunakan HPLC. Kolom yang digunakan adalah Nukliusil 100-5C18, 7.6×300 mm, GL Science. Detektor L V diatur pada $257 \mathrm{~nm}$. Fase mobile adalah larutan $0,1 \mathrm{M} \mathrm{KH}$, 'PO4 yang mengandung $0,5 \%$ (W/V) asam metafosforik, dengan $\mathrm{pH}$ dibuat 3,8 menggunakan $4 \mathrm{~N} \mathrm{NaOH}$. Laju aliran adalah $0,8 \mathrm{~mL} / \mathrm{menit}$. Persiapan contoh, pakan $(0,3 \mathrm{~g}$ dalam keadaan kering) dan larva $(0,5 \mathrm{~g}$ dalam keadaan batsah) disuspensikan dalam $5 \mathrm{~mL}$ larutan fase mobil dian ditambah 0,1\% DTT (dithiothreitol) lalu diaduk sampai homogen. Dalam persiapan pakan sebclum diaduk ditambahkan enzim phosphatase untuk memisahkan ikatan garam fosfat dengan L-asam askorbik (vitamin $\mathrm{C}$ ) sehingga vitamin $\mathrm{C}$ dalam

Tabel 1. Komposisi pakan percobaan (\%).

Table 1. Composition of test diets (\%).

\begin{tabular}{lrrrr}
\hline \multicolumn{1}{c}{ Bahan (Ingredients) } & 0 ( A ) & 500 ( B ) & 1000 ( C ) & $\mathbf{1 5 0 0}$ ( D ) \\
\hline Tepung udang (Shrimp) meal) & 11.00 & 11.00 & 11.00 & 11.00 \\
Tepung cumi (Squid meal) & 6.00 & 6.00 & 6.00 & 6.00 \\
Tepung ikan (Fish meal) & 38.00 & 38.00 & 38.00 & 38.00 \\
Kuning telur (Eggs yolk) & 6.00 & 6.00 & 6.00 & 6.00 \\
Tepung beras (Rice meal) & 16.30 & 16.30 & 16.00 & 16.00 \\
Vitamin mix-1 & 2.00 & 2.00 & 2.00 & 2.00 \\
Mineral mix-2 & 3.00 & 3.00 & 3.00 & 3.00 \\
Minyak cumi (Squid oil) & 6.00 & 6.00 & 6.00 & 6.00 \\
Lesitin (Leshitine) & 3.00 & 3.00 & 3.00 & 3.00 \\
BHT & 10.00 & 0.10 & 0.10 & 0.10 \\
Sellulose (Cellulose) & 0.60 & 0.55 & 0.50 & 0.45 \\
Vitamin C & 0.00 & 0.05 & 0.10 & 0.15 \\
Zein & 8.00 & 8.00 & 8.00 & 8.00
\end{tabular}

1) Vitamin mix. (mg/kg diet): Thiamine-HCl 5, riboflavine 5. phyridoxine-HCl 4, cyanocobalamine U.u.". nikotine 20. D-calcium phantotenate 20, choline chloride 360 . D-biotine 0,4 , inositol 200 . fulic acid $1 . ;$.

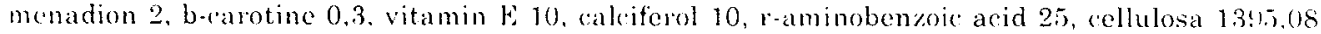

2) Mineral mix (mg/100 g diet): fe-citrate 95.7. MgSO, 215,77. K, HPO, 774,6, NaH,PO4 281.t. Ca-lactalle $100 \%$. 
pakan dapat dibandingkan dengan vitamin $\mathrm{C}$ standar (L-asam askorbik murni). Setelah itu disentrifus pada kecepatan $3000 \mathrm{rpm}$ selama 30 menit. Supernatannya dilewatkan sep-pak cartridge 0,8 (Waters, Millipore Corp., USA), kemudian disaring dengan saringan membran 0,45 mikro meter. Contoh sudah siap disuntikkan pada HPLC. Total vitamin C (L-ascorbic acid) pada pakan dan tubuh larva ditentukan dengan menggunakan kurva standar.

Percobaan ini mengunakan rancangan acak lengkap dengan tiga ulangan. Adapun peubah yang diamati meliputi perkembangan bobot setiap lima hari setelah diberi pakan percobaan, sintasan dan pertumbuhan larva pada akhir percobaan. Di samping itu, pada saat berakhirnya percobaan dilakukan uji tambahan terhadap larva untuk melihat kemampuannya menerima stres dari setiap perlakuan. Caranya, larva dikumpulkan sesuai dengan perlakuan, diambil 10 ekor secara acak dan ditempatkan dalam saringan teh yang dialas dengan kertas tissu, agar airnya tersedot. Larva dibiarkan selama enam menit, setelah itu larva dikembalikan ke dalam bak volume $30 \mathrm{~L}$ yang berisi air laut. Kemudian diamati sintasan larva setelah mendapat stres. Setiap perlakuan diulang sampai empat kali. Peubah-peubah ini diuji dengan analisis ragam untuk melihat pengaruh dari setiap perlakuan.

\section{HASIL DAN BAHASAN}

Pakan yang ditambah vitamin $\mathrm{C}$ dari jenis Lascorbyl-2-phosphate Mg (AAP) sebesar 0, 5.00, 1.000 , dan $1.500 \mathrm{mg} / \mathrm{kg}$ pakan mengandung protein, lemak, serat, abu, dan kesetaraan vitamin C pakan dengan vitamin $\mathrm{C}$ murni (standar) seperti pada Tabel 2. Pakan percobaan mengandung protein kasar 39,52-40,12\%, lemak 14,96-15,40\% dan abu 8,82-9,01\%. Penambahan AAP dalam pakan sebanyak 0 (A), 500 (B), 1000 (C), dan $1500 \mathrm{mg} / \mathrm{kg}$ pakan (D) berturut-turut setara dengan 0, 190, 370, dan $540 \mathrm{mg} / \mathrm{kg}$ pakan vitamin C murni (standar).
Perkembangan bobot larva bandeng yang diberi pakan percobaan untuk semua perlakuan dapat dilihat pada Gambar 1. Dari Gambar 1 terlihat bahwa makin tinggi kandungan vitamin $\mathrm{C}$ dalam pakan, perkembangan bobotnya cenderung lebih cepat. Di samping itu waktu responnya juga lebih pendek. Pada kandungan vitamin C 500-1.500 mg/ kg pakan waktu responnya hanya lima hari setelah pemberian pakan, sedangkan dengan vitamin $\mathrm{C}$ sebesar $0 \mathrm{mg} / \mathrm{kg}$ pakan waktu respon baru terlihat 10 hari setelah pemberian pakan.

Sintasan dan pertumbuhan spesifik selama percobaan disajikan pada Tabel 3. Dari analisis ragam terlihat bahwa sintasan larva bandeng yang diberi pakan dengan kandungan vitamin C 500, 1.000 , dan $1.500 \mathrm{mg} / \mathrm{kg}$ pakan tidak berbeda nyata $(P>0,05)$, namun berbeda nyata $(P<0,05)$ dengan pakan yang tidak diberi vitamin C. Dengan demikian vita min C dalam bentuk AAP $500 \mathrm{mg} / \mathrm{kg}$ pakan sudah cukup dalam meningkatkan sintasan larva.

Berdasarkan analisis ragam dari tingkat pertumbuhan spesifik (Tabel 3), terlihat bahwa pada larva yang diberi pakan dengan kandungan 0, 500 . dan $1.000 \mathrm{mg} / \mathrm{kg}$ tidak berbeda nyata $(P>0,05)$, namun pakan dengan kandungan 0 dan $500 \mathrm{mg} / \mathrm{kg}$ berbeda nyata dengan pakan yang mengandung vitamin C $1.500 \mathrm{mg} / \mathrm{kg}$ pakan. Pertumbuhan spesifik larva bandeng yang diberi pakan dengan kandungan vitamin C 1.000 dan $1.500 \mathrm{mg} / \mathrm{kg}$ tidak berbeda nyata $(\mathrm{P}<0,05)$. Hasil ini dapat memberikan gambaran bahwa pakan larva bandeng yang baik sebaiknya mengandung vitamin C $500-1.500 \mathrm{mg} / \mathrm{kg}$ pakan. Vitamin $\mathrm{C}$ sangat mudah larut dalam air, sedangkan pakan yang diberikan pada larva berukuran sangat kecil (200-400 mikron), sehingga kadar vitamin $\mathrm{C}$ dalam pakan yang berada dalam media air akan menurun sangat cepat. Berbeda dengan pakan ikan yang lebih besar seperti yuwana atau ikan sejari, di mana ukuran pakan lebih besar dan makannya lebih cepat, maka peluang ber-

Tabel 2. Hasil analisis pakan.

Table 2. The result of feed analysis.

\begin{tabular}{lccccc}
\hline $\begin{array}{c}\text { Pakan } \\
\text { Diets }\end{array}$ & $\begin{array}{c}\text { Protein kasar } \\
\text { Crude protein } \\
(\%)\end{array}$ & $\begin{array}{c}\text { Lemak } \\
\text { Lipid } \\
(\%)\end{array}$ & $\begin{array}{c}\text { Abu } \\
\text { Ash } \\
(\%)\end{array}$ & $\begin{array}{c}\text { Serat } \\
\text { Fibre } \\
(\%)\end{array}$ & $\begin{array}{c}\text { Vitamin C } \\
\text { L-Ascorbic acid } \\
(\mathbf{m g} / \mathbf{K g})\end{array}$ \\
\hline A $(0)$ & 40.01 & 15.21 & 8.93 & 6.21 & 0.00 \\
B (500) & 39.52 & 15.40 & 9.01 & 5.96 & 190.00 \\
C (1,000) & 40.12 & 14.96 & 8.82 & 5.88 & 370.00 \\
D (1.500) & 40.00 & 15.11 & 9.21 & 5.82 & 540.00 \\
\hline
\end{tabular}




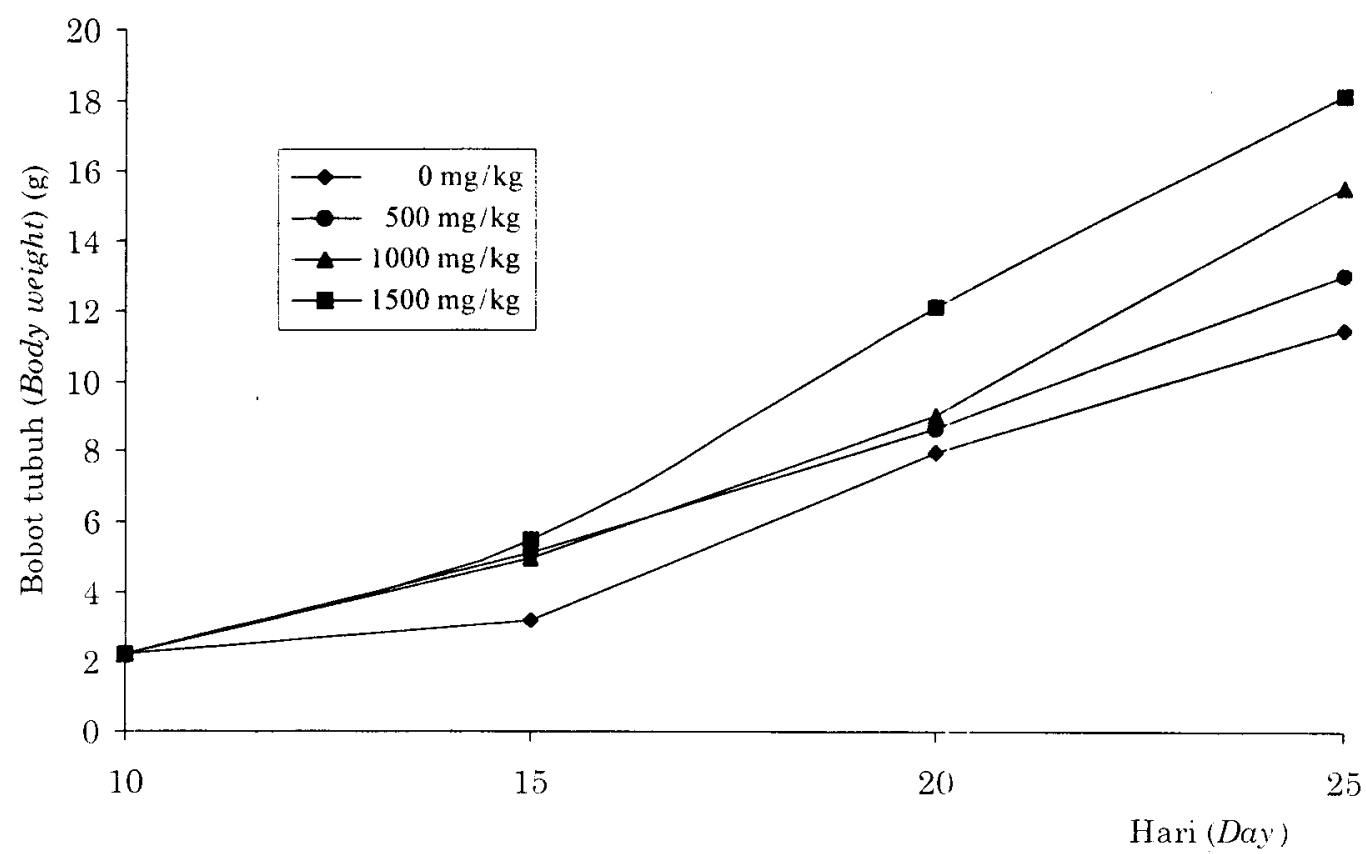

Gambar 1.Perkembangan bobot larva bandeng yang diberi pakan dengan kandungan vitamin C (AAP) yang berbeda.

Figure 1. Development of milkfish larvae body weight during feeding with different vitamin $C$ contents.

Tabel 3. Sintasan dan tingkat pertumbuhan spesifik larva bandeng yang diberi pakan dengan kandungan vitamin $\mathrm{C} 0,500,1000$, dan $1500 \mathrm{mg} / \mathrm{kg}$ pakan.

Table 3. Survival and specific growth rate of millfish larvae fed with vitamin C content of $0.500,1000$, and $1500 \mathrm{mg} / \mathrm{kg}$ feed.

\begin{tabular}{|c|c|c|}
\hline $\begin{array}{c}\text { Kandungan vit. C pakan } \\
\text { Dietary vit. } C \\
(\mathrm{mg} / \mathrm{kg})\end{array}$ & $\begin{array}{c}\text { Sintasan } \\
\text { Sul'vival rate } \\
(\%)\end{array}$ & $\begin{array}{l}\text { Tingkat pertumbuhan } \\
\text { spesifik } \\
\text { Specific growth rate }\end{array}$ \\
\hline $0(\Lambda)$ & $32.65 \pm 3.23^{\prime \prime}$ & $0.1257^{\mathrm{ath}}$ \\
\hline $500(\mathrm{~B})$ & $39.14 \pm 1.82^{b}$ & $0.1352^{b}$ \\
\hline $1,000(\mathrm{C})$ & $38.36 \pm 3.18^{l}$ & $0.1496^{\mathrm{bc}}$ \\
\hline $1,500(\mathrm{D})$ & $38.71 \pm 2.29^{l}$ & 0.1617 \\
\hline
\end{tabular}

Angka dalam kolom diikuti dengan notasi huruf yang sama tidak berbeda nyata $(P>0),(1,5)$.

Values in columnss followed by the same superscript are net significantly different (P>110.5).

kurangnya vitamin $\mathrm{C}$ pada pakan yang dimakan lebih sedikit dibandingkan dengan pakan untuk larva. Oleh karena itu pakan larva sebaiknya mengandung vitamin yang lebih tinggi sehingga kebutuhannya terpenuhi. Menurut Kosutarak et al. (1995), dosis tinggi vitamin $\mathrm{C}(500 \mathrm{mg} / 100 \mathrm{~g}$ pakan; kira-kira 100 kali lebih tinggi dari kebutuhannya) yang dita mbahkan pada pakan tidak bersifat racun terhadap ikan red sea bream berukuran $3,36 \mathrm{~g}$.
Hasil penelitian Boonyaratpalin el al. (1990) menunjukkan bahwa ikan kakap ukuran sejari $(0,83-0,87 \mathrm{~g})$ yang dipelihara dalam kondisi air laut membutuhkan vitamin $C$ dalam pakan sebanyak $700-2.500 \mathrm{mg} / \mathrm{kg}$ pakan. Pada ikan Allantic salmon yang diberi pakan dengan kandungan vitamin $C$ dari jenis ascorbyl-2-phospate yang setara dengan $0,20,60$, dan $100 \mathrm{mg}$ asam askorbat (AA)/kg pakan selama lima bulan tidak menunjukkan perbedaan 
dalam pertumbuhan, namun indeks hepatosomatik menurun dengan meningkatnya kadar vitamin $\mathrm{C}$ dalam pakan (Waagbó \& Sandnes, 1996).

Vitamin C berperan penting dalam biosintesis karnitin dalam jaringan tubuh. Karnitin ini memegang peran dalam transpor asam lemak ke dalam mitochondria. Asam lemak dioksidasi untuk menghasilkan energi. Kekurangan vitamin C dalam jaringan akan menyebabkan berkurangnya produksi energi dan melemahnya tubuh (Horning et al., 1984). Vitamin C dapat meningkatkan absorbsi zat besi dari usus. Zat besi diketahui dapat berperan dalam peredaran oksigen dalam tubuh. Di samping itu, vitamin $\mathrm{C}$ dapat berperan dalam pembentukkan kolagen (Kosutarak et al., 1995). Terhambatnya pembentukan kolagen akan menyebabkan jaringan pelekat akan melemah. Hal ini dapat menyebabkan terjadinya pertumbuhan tulang yang tidak sempurna (Horning et al., 1984). Menurut Miyasaki et al. (1995) bahwa vitamin C juga dapat mencegah terjadinya metabolisme lemak yang abnormal, seperti berkurangnya kadar asam lemak rantai panjang dan terganggunya penggunaan lemak tubuh selama tidak makan.

Meningkatnya kandungan vitamin C dalam pakan akan cenderung meningkatkan kandungan vitamin $\mathrm{C}$ dalam tubuh dan daya tahan larva terhadap stres meningkat (Tabel 4). Dari Tabel 4 terlihat bahwa daya tahan benih yang diberi pakan dengan kandungan vitamin $\mathrm{C} 0$ dan $500 \mathrm{mg} / \mathrm{kg}$ pakan tidak berbeda nyata $(P>0,05)$. Namun larva yang diberi pakan dengan kandungan vitamin $\mathrm{C}$ 1.000 dan $1.500 \mathrm{mg} / \mathrm{kg}$ pakan daya tahannya lebih tinggi dari yang diberi pakan dengan kandungan vitamin $\mathrm{Clebih}$ rendah. Hal ini juga dapat ditunjukkan pada ikan lele yang mempunyai bobot rata-rata
$3 \mathrm{~g}$ diberikan pakan dengan kandungan vitamin C $>60 \mathrm{mg} / \mathrm{kg}$ pakan daya tahan tubuhnya akan meningkat (Li \& Lovell, 1985). Di samping itu, studi pada ikan rainbow trout dan Atlantic salmon diclapat bahwa penurunan kadar vitamin $\mathrm{C}$ dalam pakan dapat menekan sistem daya tahan tubuh (Verlhac \& Gabaudan, 1994). Pada ikan air tawar Nemacheilus simatus, daya tahan tubuh terhadap racun juga meningkat dengan meningkatnya kadar vitamin C dalam darah atlantic salmon (Magare \& Kulkarni, 1996).

Salah satu indikator bahwa ikan/hewan terkena stres adalah meningkatnya kadar hormon kortison dalam darah (Thaxton \& Pardue, 1984). Waagbo \& Sandnes (1996) melakukan percobaan pada ikan Atlantic salmon dengan memberi pakan berkadar vitamin $C$ yang setara dengan 0, 20,60, dan 100 $\mathrm{mg} / \mathrm{kg}$ pakan selama lima bulan. Setelah itu ikan tersebut dipindahkan ke dalam air laut (34 ppt) selama 24 jam, diperoleh indikasi bahwa kadar kortison dalam darah menurun secara proporsional sesuai dengan peningkatan kadar vitamin $\mathrm{C}$ dalam pakan. Hal ini menunjukkan bahwa vitamin $\mathrm{C}$ berperan dalam mengurangi stres. Thomson et al. (1993) mendapatkan bahwa ikan Atlantic salmon yang diimunisasi dengan Aeromonas salmonicida menunjukkan produksi antibodinya menurun akibat stres, dan antibodi yang spesifik lebih tinggi pada ikan yang diberi pakan dengan kadar vitamin $\mathrm{C}$ rendah dibandingkan ikan yang diberi kadar vitamin $\mathrm{C}$ tinggi.

\section{KESIMPULAN}

Pakan yang mengandung vitamin $\mathrm{C}$ dalam bentuk AAP $500 \mathrm{mg} / \mathrm{kg}$ pakan yang setara dengan $190 \mathrm{mg}$ vitamin C murni/kg pakan sudah cukup

Tabel 4. Kandungan vitamin C dalam tubuh larva pada akhir percobaan dan sintasan larva ikan bandeng yang ditempatkan di udara selama enam menit.

Table 4. Vitamin C content of larvae at the end of experiment and survival rate of millfish fry after being exposed to the air for six minutes.

\begin{tabular}{ccc}
\hline $\begin{array}{c}\text { Kandungan vitamin } \\
\text { C pakan } \\
\text { Dietary vitamin } C \\
(\mathrm{mg} / \mathrm{kg})\end{array}$ & $\begin{array}{c}\text { Sintasan } \\
\text { Survival rate }\end{array}$ & $\begin{array}{c}\text { Kandungan vitamin C dalam tubuh } \\
(\mathrm{mg} / 100 \mathrm{~g} \text { bobot basah) }\end{array}$ \\
\hline (\%) & $\begin{array}{c}\text { Vitamin C content in the body } \\
(\text { mg/100 } \mathrm{g} \text { wet weight })\end{array}$ \\
500 (B) & $10.0 \pm 8.17^{\mathrm{a}}$ & 0.0096 \\
1,000 ( C) & $15.0 \pm 5.77^{\mathrm{n}}$ & 0.0125 \\
1.500 ( D ) & $35.0 \pm 3.18^{\mathrm{b}}$ & 0.0151 \\
& $45.0 \pm 12.91^{\mathrm{b}}$ & 0.0192 \\
\hline
\end{tabular}

Angka dalam kolom diikuti dengan notasi huruf yang sama tidak berbeda nyata $(P>0,05)$.

Values in columns followed by the same superscript are not significantly different $(P>0.05)$. 
untuk meningkatkan sintasan larva bandeng. Akan tetapi untuk pertumbuhan larva lebih cepat dan daya tahan tubuh terhadap stres yang baik diperoleh dengan pakan yang mengandung vitamin $\mathrm{C}$ dari jenis AAP sebesar 1.000-1.500 $\mathrm{mg} / \mathrm{kg}$ atau yang setara dengan $370-540 \mathrm{mg}$ vitamin $\mathrm{C} / \mathrm{kg}$ pakan

\section{DAFTAR PUSTAKA}

Andrews. J.W. and Murai, T. 1975. Studies on the vitamin $\mathrm{C}$ requirement of channel catfish (Ichtalurus punctatuss). J. Nutr. 105:557-561

Boonyaratpalin, M., Unprasert. N. and Buranapannidgit. J. 1990. Optimal suplementary vitamin $\mathrm{C}$ level in seabass fingerling diets. In Takeda, T. and T. Watanabe (Eds). Proceeding Third Int. Symp. on feeding and Nutr. in Fish. Toba Aug. 28-Sept. 1, 1989. Japan. pp. 149-157

Gadient. M. and Fenster. R. 1994. Stability of ascorbic acid and other vitamins in extruded fish feeds. Aquaculture. 12- (1-4): $207-211$.

Halver. J.E.. Ashley. L.M. and Smith, R.M. 1969. Ascorbic acid requirement of coho salmon and rainbow trout. Trans. Amer. Fish. Soc., 98: 762-771.

Horning. D.. Glatthair. B. and Moser, U. 1984. General aspect of ascorbic acid function and metabolism. In Tawaker. F.J. and J. Monsgaard (Eds). Proceeding of Ascorbic Acid in Domestic Animals Workshop. Skjoldenesholm. Sept.. 1983. The Royal Denish Aquacultural Society. Copenhagen. pp. $2-24$

Ikeda. S. and Sato. M. 1965. Biochemical studies on Lascorbic acid in aquatic animal IV: Metabolism of L-ascorbic acid-1-C14 in carp. Bull. Jpn. Soc. Sci. Fish.. 31: 814-817.

Kitamura. S.. Ohara. S.. Suwa, T. and Nakagawa. K. 1965 Studies on vitamin requirements of rainbow trout . Salmo gairdneri I: on ascorbic acid. Bull. Jpn. Soc. Sci. Fish.. 31:828-834.

Kosutarak. P.. Kanazawa. A.. Teshima. S. and Koshio. S. 1995. Interaction of L-ascorbyl-2-phosphate $\mathrm{Mg}$ and oxized fish oil on red sea bream juveniles. Fish. Sc.i. 61(4): 696-702.

Li. Y. and Lovell, R.T. 1985. Elevated levels of dietary ascorbic acid icrease immune responses in channel catfish. J. Nutr. 115(1): 123-131.
Lovell. R.T'. 1973. Essentiality of vitamin C in feeds for intensively fed cageds channel catfish. J. Nutr. 103:134-138.

Lovell, R.T. and Neggar, G.O.E. 1990. Vitamin Cactivity for L-ascorbic acid. L-ascorbyl-2-sulfate. and L. ascorby]-2-phosphate-Mg for cannel catfish. In Takeda. M. and T. Watanabe (Eds). Procereding Third Int. Symp. on feeding Nutr. in Fish. Toba aug. 28 . Sept. 1, 1989. Japan. pp 159-165

Magare. S.R. and Kulkarni, A.B. 1996. Effect of tond poison on ascorbic acid level in the fish. Nemachelus sinuatus. Envron. Ecol. 14 (2): 488-494.

Miyasaki. T. 1995. Metabolism and physiological activity of ascorbyl-2-phosphate in fish. J. Shimonoseki Univ. Fish. 43(2): 45-107.

Miyasaki, T., Sato, M., Yoshinaka. R. and Sakaguchi. M.. 19915. Effect of vitamin $\mathrm{C}$ on lipid and carnitine metabolism in rainbow trout. Fish. Sri.. 61(3): 501. 505.

Poston, H.t. 1967. Effect of L-ascorbic acid on immature brook trout. New York State. Cons. Dept.. Fish. Re's. Bull.. 30:30: 46-51.

Robinson. E.H. 1984. Vitamin requirement, Nutrition and feeding of channel catfish. (Revised) Robinson. E.M. and Lovell, R.T. (Eds). South Cooperative Serie's Bulletin No 296: 21-25.

Thaxton. J.P. and Pardue, S.I. 1984. Ascorbic acid and physiological stress. In Tagwaker F.J. and J. Monstgrard (Eds). Proceeding of Asrorbir Acid in Domestic Animals Workshop. Skjoldenesholm. September 1983. The Royal Danish Aqua. Soc. Copenhagen. pp. $25-31$

Thomson, I., White. A., Fletcher, T.C., Honlelian. D.F. and Secombes. C.J. 1993. The effect of stress on immune respone of Atlantic salmon (Salmo selar L.) fed diets containing different amount of vitamin C. Aquaculture. 114(2): 1-18

Waagbo, F. and Sandnes, K. 1996. Effects of dietary vitamin $\mathrm{C}$ on growth and parri-smolt transformation in Atlantic salmon. Salmo salar L. Aquacult. Nutr. 2(2): 65-69.

Yano. Y. 1975 Nutritional studies of red seabream. In Price, K.S., W.N. Shaw and K.S. Danberd (Eds). Proceeding of the First Inter. Cof. on aquaculture Nutrition. Univ. of Delaware. pp 34-39 